\title{
Some Ways of Semantisation of the Vocabulary in the Sphere of the International Tourist Business in the Teaching of Foreign Language
}

\author{
Boryana Prashtilova \\ College of Tourism \\ University of Economics - Varna \\ 77 Knyaz Boris I Blvd. \\ Varna, Bulgaria \\ E-mail: boryan_a@rambler.ru
}

\begin{abstract}
In the present article the most used ways for semantisation of the tourist vocabulary in teaching the foreign language (and more concrete in teaching Russian and English as a foreign language) at the Universities, which offer education in "Tourism" speciality are considered. The following ways of semantisation are considered: semantisation through translation, semantisation through an explanation of the meanings of the terms with the help of demonstrative materials, semantisation through and explanation of the meanings of the terms through description, semantisation through the usage of counting, semantisation through an explanation of the type of the word by the generic one, semantisation through synonyms, semantisation through antonyms.
\end{abstract}

Keywords-education; training; semantisation; vocabulary; tourism; touristic terms foreign language

\section{INTRODUCTION}

In the contemporary 21 st.century, there are no boundaries for the communication and the contacts between the people from different nationalities. However, it is extremely important they to be able to communicate and understand each other to an understandable for them language. This is valid and for the international tourist business. For improving the quality of the tourist services is it of high importance to have employees and servicing staff in the tourist business who are proficient in the foreign languages. That is why, a main aim of the universities, offering education in the "Tourism" speciality is not only to prepare the employees in the Tourism professionally and to give them the language education needed.

According to V. Prodanovska, the teaching and "usage of foreign languages" help and they are "of an advantage for the students" "in the interconnected modern world", and "the foreign language opens doors to availabilities to work in the global economy" [1].

Z. Zhelyazkova considers, that "the language proficiency became an obligatory requirement for the modern man, and depending on the quality of the language education in privacy are the perspectives for the career development, the abilities for a better realization in life and spread of the private contacts" [1]. If we keep on thinking, we can tell that the good foreign language proficiency of the students, who teach specialties in "Tourism", is an obligatory step. Very helpful and useful in this way are the skillful ways used by the teachers in foreign language for semantisation of the necessary vocabulary of the sphere of the international tourist business. The efficiency and the good results in teaching the foreign language for the necessities of the tourism depend to a high extend of "the right selection and realization of the didactic technology of the teacher" [3], i.e. it is a matter of question for the most right, for "the appropriate selection of didactic methods, through which the teacher realizes the result educational process for its students" [3].

\section{BASIC WAYS OF SEMANTISATION OF THE NEW TERMS IN THE TEACHING OF FOREIGN LANGUAGE}

In order to view the basic means of semantisation of the unknown for the students terms of the touristic vocabulary in the teaching of foreign language (in particular Russian and English), we will concrete what is a semantisation of the vocabulary. According to E. Azimov and A. Shtukin under a semantisation of the foreign term is understood "a disclosure of the sense, of the meaning of the vocabulary unit; the process and result of the advisement of the necessary information for the content part of the vocabulary unit" [4].

In the methods of teaching of foreign languages there is a definite arsenal of means and ways for semantisation, with which help the means of the teaching vocabulary structures is revealed. Their consideration is necessary as to assure through using real and conditionally real situations. They will guarantee the right understanding and perception of the new vocabulary material by the studying.

The semantisation is "the preliminary stage, followed by automatization, in the process of which the function of the word is acquired" [5]. 
Or this is the so-called "the situational collocation of the word". This means that "the vocabulary units should be inserted from the very beginning "in the situation", and "first out of a situation, and then in a situation" [5].

This way, "the lexical habit is related to the situation in the process of talking" [5].

That is why is important to create vocabulary habits which represent "a synthesized activity of the choice of a lexical item and its correct combination with other lexemes that agrees with the original idea of speech" [5].

We agree with R. Stoyanova, that "The lexical intercultural speech habits are formed on the basis of training the acquired vocabulary. That is achieved by the repeated conscious performance of definite activities in learning communicative situations. Thanks to them, vocabulary is memorized and used in the learner's real-life personal experience [5].

R. Stoyanova notes, that "The correct definition of the lexical item, where it is firstly introduced, is of great importance for its correct acquisition and stay in one's memory" [5].

The semantisation as a process of revealing the meanings of the terms in the sphere of the touristic business can be realized by a different way. E. Solovova underlines, that "their choice depends on the peculiarity of the word itself, of the characterized peculiarities of the group of the students and of the vocabulary and professional competence of the teacher" [6].

The choice of method for semantisation in each separate case is defined by the character of the word (the term), by the stage of education and by the level of education.

According to T. Laguta and O. Verzhanskaya [7], the main approaches for semantisation of the new tourist terms are:

\section{A. Semantisation Through Translation}

In the start stage of the education, when the vocabulary of the students is not so rich, the most acceptable ways for semantisation are the translation to the native language and the demonstrative semantisation. The translation to the native language is a very old and wide spread way for semantisation of the vocabulary which is explained by its simplicity and convenience, despite of this and the fact that the learners have the ability to think at their native language, but to speak at the foreign one. All manipulations of the foreign language means lead to a translation to the native language of the learners and that is why it is necessary it to be used in the learning process purposefully and skillful.

B. Belyaev recommends in its developments the semantisation through translation to be used then when the concepts match thoroughly [8].

R. Stoyanova underlines that, the "Definition through translation is commonly encountered in cases when the teacher has mastered the learner's native language or the intermediary language. This means of introducing new vocabulary is mostly used when meeting abstract words. However, it is important that the related words from the two languages have an equal range of meaning"[7].

\section{Examples:}

eng. catering - rus. система обеспечения клиентов (пассажиров) питанием и напитками (в гостинице, на судне, на самолете, во время каких-либо общественных мероприятий и т.п.) [cistema obespecheniia klientov (passazhirov) pitaniem i napitkami (v gostinitse, na sudne, na samolete, vo vremia kakikh-libo obshchestvennykh meropriiatii i t.p.)] [9];

eng. detour - rus. отклонение от запланированного маршрута [otklonenie ot zaplanirovannogo marshruta] [9];

ng. duplex - rus. двухуровневый (двухэтажный) номер сюит (suite) [dvukhurovnevyi (dvukhetazhnyi) nomer siuit (suite)] [9];

eng. guesthouse - rus. небольшая гостиница (обычно не более 10 номеров) [nebol'shaia gostinitsa (obychno ne bolee 10 nomerov)] [9].

When the semantisation is made through translation a shorter time is spent for explaining the new vocabulary.

\section{B. Explanation of the Meanings of the Terms Helping with Demonstrative Materials}

For explaining the meanings of the terms helping with demonstrative materials it is used the so-called "direct method" ofteaching. According to T. Kapitonova, L. Moskovskin, A. Shtukin "the direct or short method represents the method of teaching of oral speech, which the conditions for natural way of studying a foreign language are created, i.e. this is a way of studying a foreign language in the process of communication of its holders" [10].

For this didactic principle Ya. A. Komenski and K. D. Ushinki have written [11], [12].

Using this method "the new vocabulary is semantized through demonstrative materials and explanations at the studying foreign language" [13]. Because the native language is not allowed during studying, there are different auxiliary means: "pictures or simple actions" [13].

This is the way of provoking different associations in the teaching of new, unknown lexical items. R. Stoyanova notes that „As far as such cultural associations are concerned, lexical items manifest themselves as concepts reflecting certain cultural connections and relations" [5]. In this way these associations reflect the historical development of a given society and convey culturology information [5]. This is the reason in the process of the foreign language teaching as R. Stoyanova notes"As a result, the process of foreign language teaching, and in particular the teaching of Bulgarian as a foreign language, demands that even at the stage where a group of new vocabulary is introduced, the learners should be instructed what concepts and associations a given word evokes in the consciousness of the native speakers" [5]. 
"In this case, the explanation of differences that emerge when interpreting the concepts may as well be carried out in the learners' native language depending on his level of competence" [5].

S. Phanaeva underlines that in the methods there are some ways of demonstrative semantisation used: a) ordinary: showing of drawings, subjects and others; b) language demonstration, including different ways of demonstration in the oral and written speech, sound records performed by masters of the artistic word, the teacher's word; c) a situative - model demonstration (demonstration through a speech act, actions) [12].

\section{Explanation of the Meanings of the Terms with a Description}

The description, as T. Laguta and O. Verzhanskaya note, can be under the form of some of a description (a definition), interpretation (for example of an interpretative terminological dictionary) or an "interpretation helping with the combination of words, a simple sentence or a comment" [7], from the foreign language and vice versa. This means of semantisation is used when we have to describe a term which is absent in the native language.

\section{Examples:}

A) Within teaching English as a foreign language in a Russian speaking auditory of students a semantisation on the native language of the students can be used [9]:

eng. advance reservation - rus. заблаговременное бронирование; часто дает возможность на получение скидок на различные услуги (проживание, транспорт) [zablagovremennoe bronirovanie; chasto daet vozmozhnost' na poluchenie skidok na razlichnye uslugi (prozhivanie, transport)] [9];

eng. available room - rus. свободный номер, номер, имеющийся в наличии [svobodnyi nomer, nomer, imeiushchiisia v nalichii] [9];

eng. вed and breakfast $/ \mathrm{BB} /$ - rus. размещение, предусматривающее завтрак, включенный в цену номера [razmeshchenie, predusmatrivaiushchee zavtrak, vkliuchennyi v tsenu nomera] [9];

eng. Business class - rus. бизнес-класс (в самолете), а также соответствующий тариф [klass (v samolete), a takzhe sootvetstvuiushchii tarif] [9];

B) Within teaching English as a foreign language a semantisation at the language of teaching can be used English:

eng. charter flight - a flight in which all seats are paid for by a travel company and then sold to their customers, usually at a lower price than normal [14];

eng. customer - a person who buys goods or services in a shop, restaurant, hotel, etc. [14];

eng. smoothie - a drink made of fruit or fruit juice, sometimes mixed with milk or ice cream [14]; eng. vacuum cleaner - an electric machine that cleans carpets, etc. by sucking up [14];

eng. youth hostel - a cheap and simple place to stay, especially for young people when they are travelling [14].

\section{Usage of Numerations}

Using this way there are words numerated, denoting the parts of this, which is marked with one word, which is semantized (a whole through parts of the whole).

\section{Examples:}

eng. menu - starters, soups, salads, main courses, quick dishes, desserts;

eng. wine list — wine, cocktails, hard and soft drinks;

eng. eating and entertainment establishments - bar, coffee shop, restaurant, wine cellar, fast food restaurant;

eng. kitchen staff - chef, rotisserie cook, larder cook, assistant cook, dishwasher/sculleryman, kitchen helper/hand.

\section{E. Explanation of the Type of the Word by the Native One}

This happens through using concepts in connection with this, which is pointed by them (generic through types).

\section{Examples:}

eng. hotel -3 star, 4 star, 5 star, 5 star hotel, hostel, motel;

eng. flight — domestic, international, charter;

eng. drink/beverage - alcoholic/hard, nonalcoholoc/soft, carbonated, fresh, natural, water, milk;

eng. carbonated drinks — Pepsi, Mirinda, Tonic water;

eng. juices - 100\% juice, $50 \%$ juice, nectar.

\section{F. Explanation Through Synonyms}

R. Stoyanova noted, that "the question of the existence of the synonyms in the separate systems of terms are one of the most controversial question in the terminology" [15].

Some linguists (A. S. Gerd, N. P. Kuzmin) [15] consider that the synonyms are among the terms for unwanted appearance, and other "admit the presence of synonyms in the systems of the terms and study the synonyms relations between the terms (D. I. Vinokurov, G. A. Alexandrova)“ [15].

According to R. Stoyanova „The use of synonyms in definition is an extremely important means of revealing the lexical meaning of the new word". Synonymy enriches and expands the learner's lexical competence" [5]. She also thinks that "when teaching at the beginner's level, the use of synonyms is somewhat relative, because words are presented as identical in meaning with their equivalents" [5]. In a later stage of the education, when the students are advanced, they can use also and "synonym series" [5].

K. Smolina points 4 criteria for the presence of synonyms and namely: closer (but not identity to the meanings of the 
words); identity (only); interchangeability (ability for use in one and the same or partly compatible to the character of the vocabulary compatibility contexts); neutralization (disappearing of the semantic differences in the context) [16].

The synonyms in the terms is of high importance when understanding the new, unknown terms of the foreigners. T. Laguta and O. Verzhanskaya note, that the most valuable are the terms - synonyms, one of which is own (i.e.home) and the other one - foreign (mostly occupied by the English language) [7].

\section{Examples:}

rus. все включено [vse vkliucheno] = rus. ол инклюсив [ol inkliusiv], eng. All inclusive;

rus. гостиница [gostinitsa] = rus. отель [otel'], eng. hotel;

rus. давать на чай [davat' na chai], eng. to tip= rus. давать чаевые [davat' chaevye], eng. to give a tip;

rus. досуг [dosug], eng. leisure = rus. отдых [otdykh ], eng. vacation;

rus. заказывать [zakazyvat'], eng. to order = rus. бронировать [bronirovat'], eng. to book;

rus. путешествие [puteshestvie], eng. Trip = rus. круиз [kruiz], eng. cruise= rus. турне [turne], eng. tour; guide.

rus. экскурсовод [ekskursovod] = rus. гид [gid], eng. a

A negative thing of the semantisation through synonyms is that, it is an approximate, and the differences between the synonyms should be explained additionally. This way of semantisation is considered for most effective, for the basic and the closing stage of the education.

\section{G. Explanation Through Antonyms}

In the methods of teaching on foreign language there have been arguments leaded for a very long time regarding this way of semantisation. There are different opinions some of them for its forbidding and some of them for its acceptance. It is considered that this way is not always strict, because there are no full antonyms and it counts on the mostly known terms for the learners. The advantages of this way of semantisation are concluded in this, that it helps to strict the semantic nests of the words and it saves time for the education process. Although the contradictive opinions about this means of semantisation, it is considered that this is one of the most effective methods for semantisation of the tourist terms. The special combining of the pair terms helps to understand their meanings and to remember them better and easier. The semantisation of the antonym terms in the sphere of the tourist business can be represented to the learners by a presentation, which the concrete meaning of the term is represented with a definition and in a context, and not only through its connection as an antonym pair.

Examples:

rus.: $\quad$ зарегистрироваться (в гостинице) [zaregistrirovat'sia (v gostinitse)], eng. check in (at a hotel) $\neq$ rus. выписаться (из гостиницы) [vypisat'sia (iz gostinitsy)], eng. check out (of a hotel);

rus. открытие [otkrytie], eng. opening $\neq$ rus. закрытие [zakrytie], eng. closing;

rus. запрет [zapret], eng. a ban, $\neq$ rus. разрешение [razreshenie], eng. a permission;

rus. провожающий [provozhaiushchii], eng. see off $\neq$ rus. встречающий [vstrechaiushchii], eng. receive;

rus. взлететь [vzletet'], eng. to take off $\neq$ rus. приземлиться [prizemlit'sia], eng. to land.

It should be noted, that this method of semantisation is available only when the word "antonym", which is used for explaining a new word is already known to the foreign learners.

\section{CONCLUSION}

R. Stoyanova consideres, that "in the modern worldwide university education the problem of the multicultural communication is very actual and popular" [17]. The multicultural communication, on its side represents one the basic factors for the tourism and the dominant for the international touristic action [18]. The specification of the tourist auditory influence directly the requirements of the multicultural communicative competence of the specialists, working in the sphere of tourism [18].

The requirements for a high qualification assume a good communicative language culture. That is why in the universities and colleges (in privacy, the University of Economics - Varna and the College of Tourism - Varna to the University of Economics Varna) a very high attention is paid regarding the learning of foreign languages English, Russian, German, French. The main function of the learned foreign languages is to develop the oral speech abilities of the students and to form abilities for usage of the foreign languages as a means for communication. But this is impossible without a vocabulary of known words. The students must learn to combine one words with another, and by this way to create a speech-thinking activity. It is of high importance for the learning environment they to create such conditions, which the learning material to provoke the thinking and memory. The learners not only have to listen and speak, but to switch on their visual and associative memory. That is why within the education of the students learning different specialities of Tourism it is very important the right choice of the way of semantisation according to the particularities of the tourist term, and this way should be compliant to the level of learning of the students.

Nowadays, the different ways of semantisation are used, which allow to awake the interest and activity during the education of foreign language. It is established that in the beginning stage of education is better to be used demonstrative ways of semantisation (demonstration through illustrations and subjects, gestures and mimics), and little by little to change to verbal ones (usage of definitions, antonyms and synonyms, combined examples, illustrative situations - written and oral and etc.). The verbal ways allow 
to explain more abstractive concepts and to develop the language abilities of the students.

Our work confirms the pronounced of T. Laguta and O. Verzhanskaya constatation (these) that of the great variety of ways for semantisation of the vocabulary in the foreign language education, within the learning of the terms of the tourist business most of them are applied [7], and namely: semantisation through translation, explanation of the terms by description, usage of numerations, explanation of the type of the word through the native one, explanation through synonyms, explanation through antonyms.

\section{REFERENCES}

[1] Prodanovska, V. Obuchenieto po chuzhdi ezitsi v Republika Makedoniya [Teaching modern languages in the Republic of Macedonia]. Foreign Language Teaching Bulgarian Educational Journal, Volume 42, Number 6, 2015, pp. 625-632.

[2] Zhelyazkova, Z. Language Acquisition in Foreign Language Teaching - A wholistic process of interaction between the participants in the educational medium. Yearbook, Vol. 13, Stara Zagora: Trakia University of Education, 2016, pp. 105-117. URL: http://uni-sz.bg/truni4/wpcontent/uploads/pf/file/PEDAGOGICHESKI_FAKULTET/YEARBO OK 2016/All Yearbook13.pdf

[3] Teneva, M. Didactic Efficiency - factors and preconditions for its implementation, yearbook vol.13, Trakia University faculty of education, Stara Zagora, 2016. URL: http://uni-sz.bg/truni4/wpcontent/uploads/pf/file/PEDAGOGICHESKI_FAKULTET/YEARBO OK_2016/All_Yearbook13.pdf

[4] Azimov, E. G., Shtukin, A. N. Novyi slovar' metodicheskikh terminov i poniatii (teoriia i praktika obucheniia iazykam). [A new dictionary of the methodic terms and concepts] Moskva: Izdatel'stvo "IKAR", 2009 URL: http://szlavintezet.elte.hu/russian/segedanyag/tanari_ma_anyagok/azi mov_slovar.pdf

[5] Stoyanova, R. Some Issues of Vocabulary Teaching of Bulgarian as a Foreign Language. Proceedings of the International Conference on Education, Language, Art and Intercultural Communication (ICELAIC 2014), May 5 - 7, 2014, Zhengzhou, Henan, China. Paris: Atlantis Press, 2014, pp. 435-437. - (Ser. Advances in Social Science, Education and Humanities Research [ASSEHR]; Vol. 3.)

[6] Solovova, E. N. Metodika obucheniia inostrannym iazykam: Bazovyi kurs lektsii [Methods of teaching of foreign languages: Basic course of lectures]. Moskva: Prosveshchenie, 2002, p. 89.

[7] Laguta T. N., Verzhanskaia O. N. Izuchenie turisticheskoi leksiki v kurse russkogo iazyka kak inostrannogo [Learn in the tourist lexical items in the Russian language course as a foreign language] URL: $\mathrm{http}$ ://uapryal.com.ua/training/laguta- $\mathrm{t}-\mathrm{n}-$-verzhanskaya- $\mathrm{O}-\mathrm{n}-$ izuchenie-turisticheskoy-leksiki-v-kurse-russkogo-yazyika-kakinostrannogo/

[8] Beliaev, B. V. Ocherki po psikhologii obucheniia inostrannym iazykam. Posobie dlia prepodavatelei $i$ studentov [Essays in Psychology of teaching foreign languages: A tool for teachers and students]. Moskva: Prosveshchenie, 1965, p. 121.

[9] Prostakov, I. Inostrannye terminy v turbiznese, kratkii tolkovyi slovar' [Foreign terms in the tourist business, a short interpreted dictionary]. Moskva: Finansy i statistika, 2014, p. 21, p. 7, p. 8, p. 13, p. 15, p. 18, p. 31, p. 33, p. 46.

[10] Kapitonova, T. I., Moskovkin L. V., Shchukin A. N. Metody i tekhnologii obucheniia russkomu iazyku kak inostrannomu [Methods and technologies of teaching Russian language as foreign]. Pod red. A. N. Shchukina. Moskva: Russkii iazyk. Kursy, 2008, p. 27.

[11] Fedorenko, L. P. Printsipy obucheniia russkomu iazyku: posobie dlia uchitelei [Principles of the teaching Russian language: tool for teachers]. Moskva: Prosveshchenie, 1973.
[12] Pkhanaeva S. N. Semantizatsiia russkoi leksiki v prepodavanii russkogo iazyka kak nerodnogo $\mathrm{v}$ usloviiakh adygeisko-russkogo bilingvizma [Semantisation of the Russian vocabulary in teaching Russian language as a non-native in the conditions of the Addugean Russian bilingualism]. Kontsept. 2015, p. 3. № 12. URL: http://ekoncept.ru/2015/15424.htm.

[13] Dimitrova, G., Stoyanova, R., Pancheva, M., Pavlova, I., Petrova, G., Georgieva, V., Pavlova, B., Trifonova, K., Ilieva, H., Stancheva, N., Savremenni metodi i informatsionno-komunikatsionni tehnologii $v$ obuchenieto po chuzhd ezik [Modern methods of Informational Communicative technologies in the teaching of foreign language]. Sofiya: Bogianna, 2012, p. 32.

[14] Oxford Wordpower Dictionary, New 4th Edition, Oxford: Oxford University Press, 2012, p. 120, p. 185, p. 687, p. 797, p. 837

[15] Stoyanova, R., Nenova A. Termini-sinonimi v ikonomicheskata terminosistema $\mathrm{v}$ balgarski, ruski i ungarski ezik [Terms-synomims in the economical system of terms in Bulgarian, Russian and Hungarian]. Evropeyski perspektivi na natsionalnoto stopanstvo: Sbornik s dokladi ot nauchna konferentsiya $\mathrm{s}$ mezhdunarodno uchastie, Varna: Nauka i ikonomika, 2005, pp. 832-841.

[16] Smolina K. P. Tipy sinonimicheskikh otnoshenii v russkom literaturnom iazyke vtoroi poloviny XVIII veka [Types of synonym relations in the Russian literary language from the second half of the 18th. century]. Moskva: Nauka, 1977, p. 14, p.15.

[17] Stoyanova, R. Metodologicheskie osnovy sozdaniia sovremennogo kursa "Stranovedenie Bolgarii" [Methodological Bases of Creating a Modern Course - "Country Studies of Bulgaria"]. Magiia INNO: novoe $\mathrm{v}$ issledovaniii azyka i metodike ego prepodavaniia: materialy Vtoroi nauchno-prakticheskoi konferentsii (Moskva, 24-25 aprelia 2015 g.). T. 2 / otv. red. D. A. Kriachkov; Mosk. gos. in-t mezhdunar. otnoshenii (un-t) M-va inostr. Del Ros. Federatsii. Moskva: MGIMO-Universitet, 2015, pp. 219-224.

[18] Pokhodzei, G. V. Mezhkul'turnaia kommunikatsiia — neot"emlemyi factor turizma i dominanta mezhdunarodnoi turistskoi deiatel'nosti. [Intercultural communication - an integral factor of tourism and a dominant feature of international tourism activities]. Evraziiskii Soiuz Uchenykh (ESU), № 6 - 2 (6), 2014, pp. 125-126. 